\title{
LAS IGLESIAS VIRREINALES DE LOS VALLES DE LOS RÍOS HUAURA Y CHECRAS: PATRIMONIO RELIGIOSO Y TURISMO EN LA SIERRA DE LIMA
}

\author{
COLONIAL CHURCHES OF HUAURA AND \\ CHECRAS' RIVER VALLEYS: RELIGIOUS HERITAGE \\ AND TOURISM IN THE SIERRA OF LIMA
}

Sara González Castrejón

British Academy, Reino Unido

\section{RESUMEN}

Se da a conocer los templos virreinales de los valles de los ríos Huaura y Checras en la sierra de Lima, sorprendentes ejemplos de arquitectura vernácula peruana con retablos barrocos y neoclásicos, pinturas murales y mobiliario histórico que además se encuentran en parajes sorprendentes. El objetivo del presente estudio es difundir su interesante historia y exponer su potencial como atractivo turístico en conexión con los recursos naturales y culturales de la zona, como lagunas, picos, aguas termales, ruinas arqueológicas, fiestas costumbristas, folklore y gastronomía típica. Para ello, analizamos estas iglesias desde el punto de vista artístico y proponemos algunas rutas fácilmente implementables.

Palabras clave: templo, evangelización, patrimonio, doctrina, dominicos, agustinos, mercedarios, Checras, Andajes, Churín, Oyón, Cochamarca.

\begin{abstract}
This article introduces the colonial temples of Huaura and Checra's river valleys in the sierra of Lima; a surprising example of Peruvian vernacular architecture with baroque and neo-classical altarpieces, mural paintings and historical furnishing which sit in spectacular natural surroundings. We aim to disseminate their interesting history and show their potential as a tourist attraction in connection with the natural and cultural resources of the area, such as lagoons, peaks, thermal waters, archaeological remains, popular festivals, folklore and local
\end{abstract}

Este es un artículo Open Access bajo la licencia Creative Commons AtribuciónNoComercial-Compartirlgual 4.0

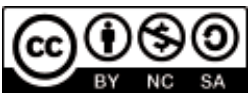


gastronomy. For that we will study these churches from the artistic point of view and suggest some routes which could be easily implemented.

Keywords: temple, evangelization, heritage, doctrine, Dominicans, Augustinians, Mercedarians, Checras, Andajes, Churín, Oyón, Cochamarca.

\section{Introducción}

Los templos rurales andinos, edificados poco después de la conquista pero aún vivos y en continua evolución, son construcciones vernáculas de gran originalidad y valor artístico, con pinturas murales, retablos barrocos y neoclásicos, y mobiliario histórico de varias épocas. Sin embargo, son comúnmente ignorados en publicaciones convencionales sobre arte peruano (excepto los de la conocida Ruta del Barroco Cusqueña), incluso cuando algunos son tan suntuosos como sus contrapartes urbanas, es por ejemplo, el caso de San Cristóbal de Rapaz.

El presente trabajo se centra en las iglesias de las antiguas doctrinas de Santo Tomás de Cochamarca, Santiago de Andajes, San Juan Bautista de Churín (Provincia Oyón) y Santiago de Maray (Provincia Huaura). Estos templos han recibido cierta cobertura institucional: en 2002 se incluyeron en el Watch de World Monuments Fund; en 2004 este organismo, a través de Robert W. Wilson Challenge to Conserve Our Heritage, realizó un inventario, exploró su condición y llevó a cabo trabajos de emergencia en varios sitios como San Agustín de Canín, San Pedro de Tongos, San Bartolomé de Picoy, Virgen de la Asunción de Oyón, Santa María Magdalena de Pachangara, San Pedro de Naván, Nuestra Señora de la Concepción de Huacho Sin Pescado, San Bartolomé de Curay y San Antonio de Lancha. En 2007 el propio World Monuments Fund, a través de Wilson Challenge, contribuyó a la limpieza, consolidación y reintegración de superficies polícromas pintadas y a la conservación de elementos arquitectónicos en siete iglesias: San Martín de Taucur, Santiago de Andajes, Nuestra Señora de la Merced de La Chimba, San Pedro de Naván, Nuestra Señora del Rosario de Quichas, Nuestra Señora de las Nieves de Mallay y San Cristóbal de Rapaz. World Monuments Fund había apoyado previamente otro proyecto en Rapaz: la consolidación y estabilización del templo. La responsable de estas actuaciones fue la arquitecta Patricia Navarro Grau, quien previamente había obtenido, junto con la también arquitecta María Isabel Beas y el historiador César Maguiña, una beca de Getty Conservation Institute para realizar un trabajo de identificación y documentación de cinco de estas iglesias: San Bartolomé de Curay, Nuestra Señora de la Merced de La Chimba, San Pedro de Naván, Nuestra Señora del Rosario de Quichas y San Cristóbal de Rapaz. Publicaron un breve resumen de su trabajo: Terra 2000 postprints: 8th International Conference on the Study and Conservation of Earthen Architecture, Torquay, Devon, UK, May 2000 (Plymouth School of Architecture, Centre for Earthen Architecture, English Heritage, ICOMOS/UK, \& Earth Structures Committee, 2000-2002). A pesar de ello, los informes completos de los trabajos realizados continúan inéditos y los templos desconocidos fuera de ámbitos locales (Obispado de Huacho, 2000; Patrimonio Perú, 2006; Patrimonio Perú y Obispado de Huacho, 2005).

Las construcciones que nos ocupan, parte integral de un paisaje agreste donde conviven con apus y huacas ancestrales, son a su modo un microcosmos de la compleja realidad social y cultural peruana del pasado y del presente, auténticos palimpsestos arquitectónicos que se han adaptado a las necesidades de la población y a las 
coyunturas del tiempo. Para empezar, aquéllos que las levantaron fueron evangelizados por diferentes órdenes religiosas, como los dominicos, agustinos y mercedarios, quienes sobrepusieron distintas experiencias y estilos de evangelización a las creencias locales, centradas en torno a una naturaleza animada. Estos lugares también servían de hogar a devociones que convivían y se solapaban, desde santos fundadores, incluyendo apóstoles, patronos de órdenes y arcángeles, a cultos marianos antiguos o más modernos (como Nuestra Señora de Copacabana, posiblemente introducida por Santo Toribio de Mogrovejo, dada su relación personal con la imagen limeña de la misma advocación) y a los sucesivos santos peruanos, que a veces se incorporaban a la escena religiosa local por iniciativa de kurakas y vecinos, no de la autoridad eclesiástica competente. Por tanto, los templos de la sierra de Lima (y de los Andes en general) no son solo palimplestos arquitectónicos, sino también construcciones simbólicas que reflejan deseos, aspiraciones e intereses personales y colectivos. Su decoración interior y exterior es también un mosaico de modas y gustos que reflejan distintas coyunturas históricas y diferentes modos de representar la autoridad divina y la humana.

La ausencia reiterada de interés hacia la arquitectura vernácula virreinal, como las iglesias que nos ocupan, se ha debido tal vez a una cuestión tan básica como el absurdo concepto de 'calidad' que gobierna el discurso estético en Occidente y a partir del cual se establece lo que está ‘bien’ o 'mal' construido o pintado; también al prejuicio arraigado de que el arte europeo es 'superior' y el virreinal derivativo o inferior, una postura que impide tener en cuenta que los conceptos de creación o creatividad, al igual que los modos de mirar y representar, pueden ser diferentes en una sociedad híbrida, en desarrollo, rural pero a la vez multicultural (se puede encontrar una buena reflexión sobre estos temas en la página web de Los Angeles County Museum of Art http:// www.lacma.org/art/exhibition/es/painted-in-mexico).

En las páginas siguientes demostraremos que estos edificios supuestamente 'rústicos' no son 'de peor calidad' que sus contrapartes urbanas: nuestro objetivo es difundir su interesante historia y exponer su potencial como atractivo turístico en conexión con los recursos naturales y culturales de la zona en que se encuentran, como lagunas, picos, aguas termales, yacimientos arqueológicos, fiestas costumbristas, folklore y gastronomía típica. A la vez, ofreceremos algunas ideas sobre posibles circuitos turísticos que nos parecen fácilmente implementables.

\section{Tipología}

Las construcciones que nos ocupan tienen un diseño uniforme: una sola nave con campanario separado, capillas abiertas en las esquinas de un extenso atrio (solo restos sobreviven), y pinturas murales que representan escenas sagradas y seculares (en mejor o peor estado de conservación). Están construidas en adobe, o en una mezcla de adobe y piedra. Tienen gruesos muros con contrafuertes y una sacristía anexa al presbiterio. Poseen techos corridos de par y nudillo y originalmente sus cubiertas eran de paja de ichu.

Estos templos solían tener capillas posas, como se apuntó. Las ceremonias y procesiones que se realizaban dentro y fuera del templo ayudaban a configurar el paisaje sagrado en esta abrupta zona de los Andes, con este tipo de construcciones fungiendo como hitos en un peregrinaje simbólico en los confines de las fiestas religiosas del pueblo. 
Muchas fachadas son simples, sin apenas decoración, pero otras más elaboradas sorprenden por su originalidad artística y además ofrecen al espectador una lección teológica, que si se interpretase y difundiese para el visitante aumentaría el potencial de estos edificios como atractivo turístico. A continuación se desarrollan algunos casos.

Hay fachadas como las de Picoy, Oyón o Quichas, que imitan la estructura de un retablo con su composición arquitectónica y esculturas en altorrelieve, por ejemplo, la fachada virreinal de Nuestra Señora del Rosario de Quichas muestra a la Virgen como Madre de Dios y Reina de los Cielos rodeada por los Cuatro Evangelistas con libros en sus manos. La de Picoy, ya republicana, tiene un programa iconográfico más complejo: en la parte alta se sitúan San Bartolomé, el santo patrón, con un demonio prisionero y encadenado (a la izquierda) y la Virgen con el Niño (a la derecha), acompañados por ángeles; entre ellos, se halla un medallón 'estilo imperio' que recuerda a una custodia solar, tiene inscrito un triángulo que simboliza la omnipotencia de Dios. Las esculturas de San Bartolomé y la Virgen adoptan posturas similares, pero el demonio prisionero y el Niño Jesús se encuentran en posiciones opuestas, aunque complementarias; mientras el primero, vencido, yace en el suelo, el segundo se muestra triunfante en los brazos de su Madre, esta es una manera clara y simple de mostrar al fiel que Dios siempre triunfa sobre el mal.

Figura 1. Fachada de San Bartolomé de Picoy.

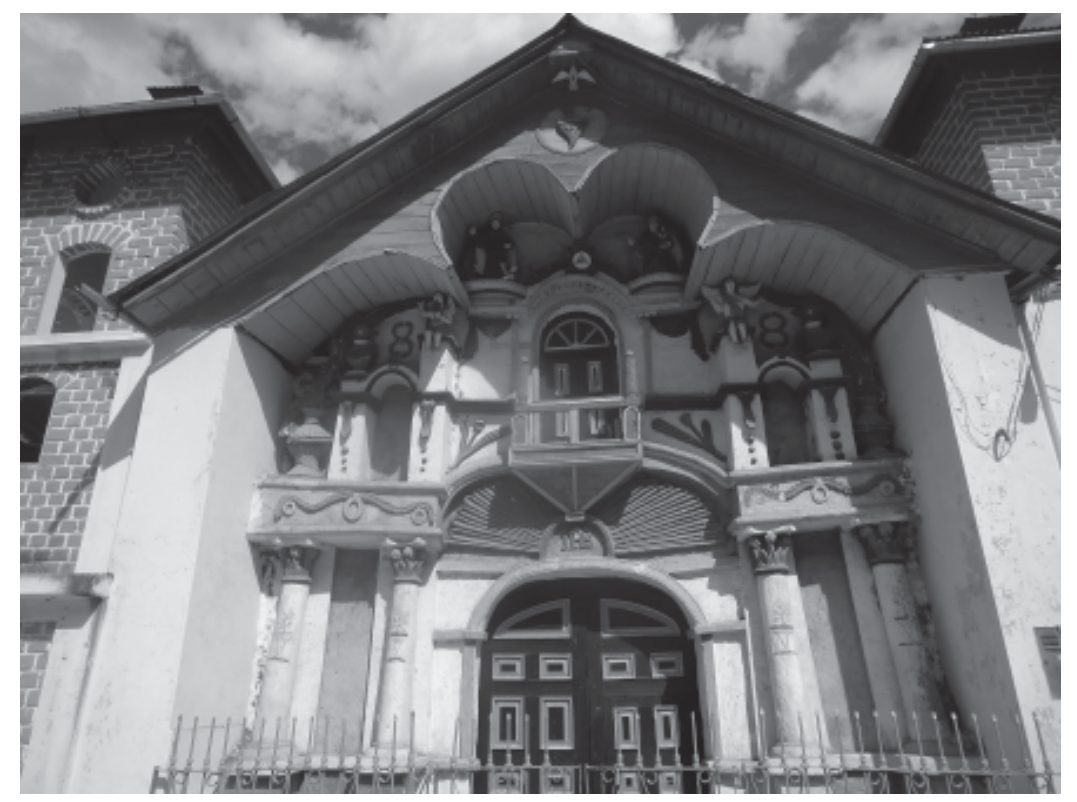

Fuente: Archivo fotográfico de Marco Antonio Arias Salazar.

Parece que en el pasado estas fachadas, tuvieran esculturas o no, estaban pintadas, y varias aún conservan parte de su policromía, como la de San Cristóbal de Rapaz, que alude al santo patrón del pueblo, o la de Andajes, donde se aprecian dos imágenes de Santiago: una como peregrino y otra como guerrero, en alusión a su supuesta aparición a los cristianos en la Batalla de Clavijo (844), donde les ayudó a derrotar al enemigo (en este caso los moros), como más tarde haría en las guerras de conquista americana; estas dos representaciones se hacen eco de las dos tallas del Apóstol que se veneran en el interior de la iglesia, la de Santiago de Infantería 
(el peregrino) y la de Santiago de Caballería (el soldado a caballo), que salen juntas en la procesión patronal y posiblemente en los inicios de la doctrina representaron a dos parcialidades locales. Otros ejemplos interesantes son las portadas de Calpa y Cochamarca, ideadas como retablos fingidos. La primera muestra un programa bastante convencional, con las efigies de San Francisco, Santo Domingo, San Juan Evangelista y San Juan Bautista (esta última muy deteriorada), pero la segunda es muy original y detalla una creencia eclesial de suma importancia para el cristiano; delimitada por columnas clásicas decoradas, en la parte superior representa la Asunción de María en el centro, flanqueada por los Arcángeles Miguel (izquierda) y Gabriel (derecha); en ambos lados de la ventana del coro se sitúan lo que parecen las efigies de Adán y Eva y el resto del espacio lo ocupa la representación de los Cuatro Evangelistas. La aparición de la Virgen en su Asunción (que replica la imagen en el nicho principal del retablo mayor) junto con los primeros padres bíblicos alude a María como Nueva Eva: la desobediencia de Eva fue deshecha por la fe de María, que es el inicio de la Iglesia, y en su Asunción resplandece el proyecto original de Dios para el hombre, el plan de poder llegar por el don de la gracia a la consumación de la Gloria (Rahner, 2002, pp. 23-24 y 46).

Figura 2. Fachada de Santiago de Andajes.

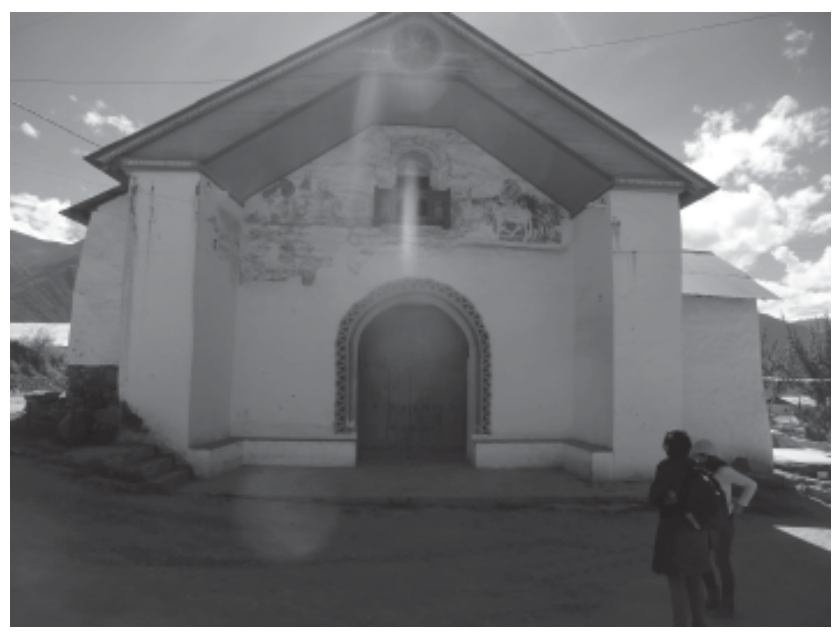

Fuente: Archivo fotográfico de Marco Antonio Arias Salazar.
Figura 3. Fachada de Santo Tomás de Cochamarca.

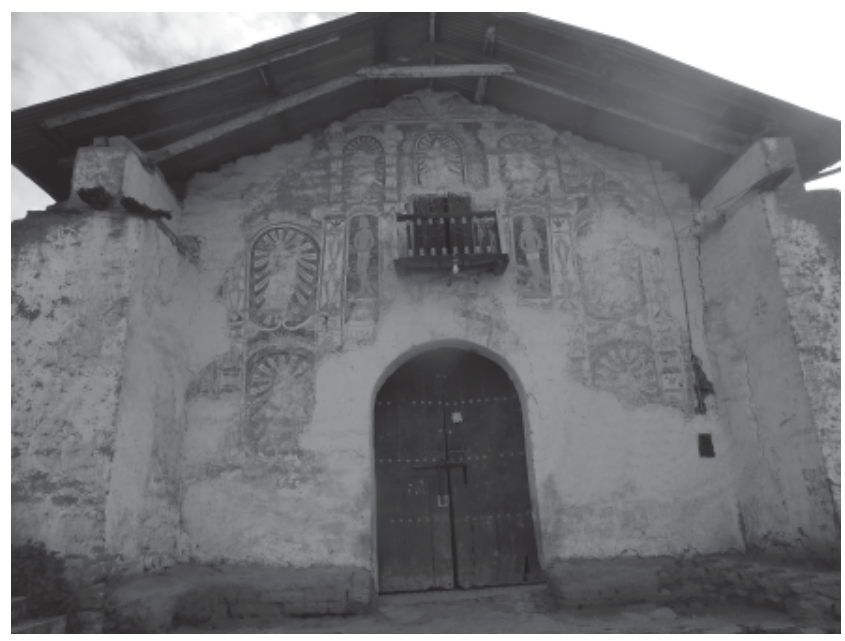

Fuente: Archivo fotográfico de Marco Antonio Arias Salazar.

Como vemos, las portadas de estos templos son en sí mismas pequeños monumentos de la arquitectura vernácula andina, no tanto por su complejidad técnica sino por su inventiva a la hora de explicar la doctrina cristiana, y también por su rareza, puesto que quedan muy pocas de las pintadas y algunas de las esculpidas han sufrido deterioro como la de San Juan Bautista de Caujul, o malas 'restauraciones', como la de Nuestra Señora del Rosario de Quichas, que ha sido repintada en acrílico por la comunidad. Su recuperación, conservación y difusión son pasos para tener en cuenta a la hora de integrar estas construcciones en circuitos turísticos coherentes.

Los edificios que nos ocupan -y las iglesias andinas en general- estuvieron desde un principio decorados con murales que embellecían sus interiores y a la vez servían de catecismo visual. Eventualmente se introdujeron 
retablos de madera y posteriormente de yeso, según cambiaron las modas y las formas de religiosidad. Es difícil saber cómo serían estos ambientes en la época virreinal: muchos murales se han perdido y otros se han cubierto con una capa de cal porque estaban deteriorados o porque en algún momento se consideraron 'pasados de moda', pero por suerte quedan algunos ejemplos que nos pueden dar una idea. El conjunto más espectacular es el de San Cristóbal de Rapaz, que contiene escenas de ángeles, Santiago, Santa Ana, la Virgen de la Piedad, el Juicio Final, Jesús con la Cruz a Cuestas, la Flagelación de Cristo, la Virgen del Rosario con San Francisco y Santo Domingo, la Virgen de la Merced con San Pedro Nolasco y San Raimundo de Peñafort, el Crucificado, Santa Rosa de Lima, San Juan Bautista, los Evangelistas, la Virgen de Cocharcas y el Señor de la Paciencia, entre otras. También existen restos en otros templos, algunos de los cuales pueden remontarse a sus inicios; es decir, principios del siglo XVII o un poco antes, cuando era común diseñar arquitecturas y retablos fingidos de inspiración clásica como los más conocidos de la iglesia de Andahuaylillas (Cusco), atribuidos a Luis de Riaño (1596-1667). Es el caso de Santiago de Andajes, donde la entrada al antiguo baptisterio se decora con una fina portada ilusoria de pilastras corintias y frontón triangular en el que aparece la paloma del Espíritu Santo en un rompimiento de gloria junto con ángeles y floreros. Sobre el dintel se aprecia la frase "QVI CREDIDET ET BAPTIZATVS FVERIT SALBUS [en lugar de 'SALVUS'] ERIT”, que proviene del versículo de la Biblia Mc 16, 16 donde se nos advierte que el sacramento del Bautismo es esencial para la Salvación (“Aquél que creyere y se bautizare se salvará”).

Figura 4. Santiago de Andajes, acceso al baptisterio.

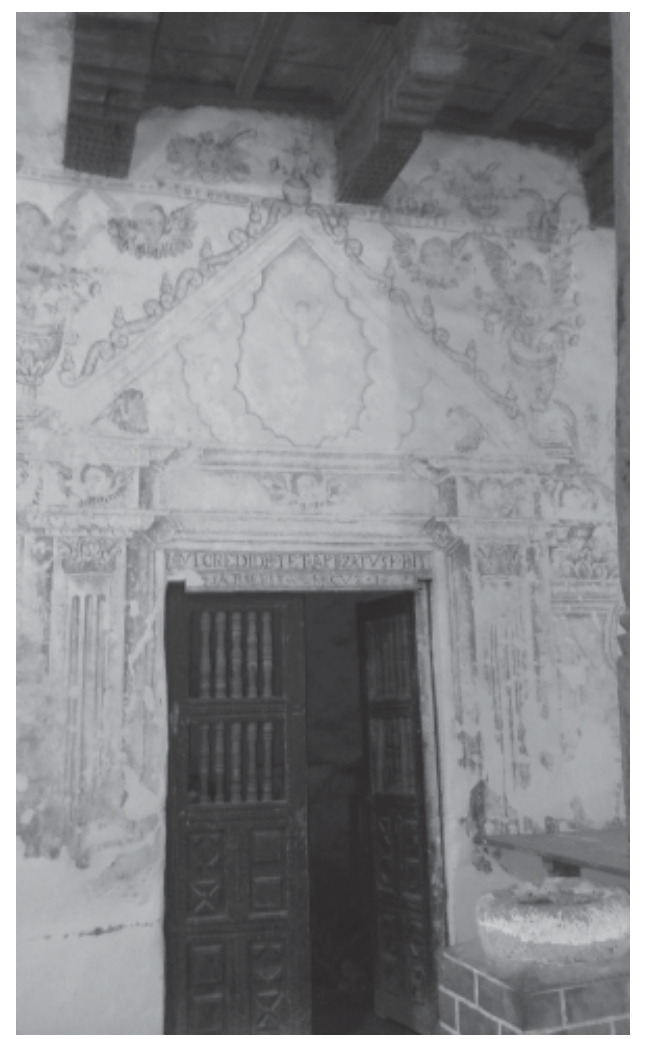

Fuente: Archivo fotográfico de Marco Antonio Arias Salazar. 
Un ejemplo destacado y que merece la pena difundir es San Agustín de Canín, cuyo presbiterio conserva pinturas murales que representan a los Doce Apóstoles en figuras de tamaño casi natural; cada uno de ellos aparece de cuerpo entero en una hornacina de mármol fingida separada de la siguiente por columnas corintias pintadas; a sus pies corre una banda de decoración floral en tonos blancos y rojos con un friso que imita arquerías ciegas y que replica armoniosamente la forma curva de los nichos que cobijan a los personajes. Mirando hacia el retablo mayor encontramos, en el lado izquierdo, a Simón el Zelote, Santiago el Menor, Andrés, Santiago el Mayor, Juan Evangelista y Pedro, y en el derecho a Tomás, Matías, Bartolomé, Simón, Felipe y Pablo. Esta representación tiene bastantes elementos en común con la del presbiterio de la iglesia de Chinchero y las de las bóvedas de Checacupe y Curahuara de Carangas (esta última en Bolivia), donde los Discípulos de Cristo aparecen en una disposición similar, aunque en posturas un poco diferentes, lo que nos habla de un posible modelo común, quizá inspirado en los mosaicos de los templos paleocristianos del Viejo Mundo, como el de la bóveda del Baptisterio de los Ortodoxos en Ravenna, Italia. En la parte superior hay otra banda con flores sobre una decoración corrida de cortinajes, elemento de influencia europea recurrente en las iglesias de la región y que se utilizaba para ennoblecer la casa de Dios como si se tratase de un palacio.

Figura 5. Presbiterio de San Agustín de Canín.

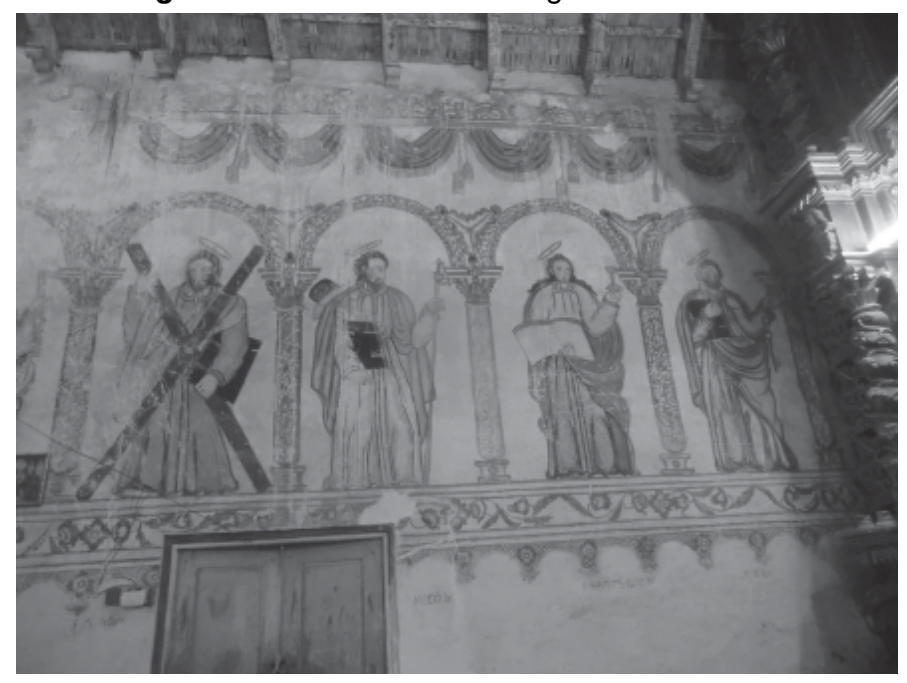

Fuente: Archivo fotográfico de Marco Antonio Arias Salazar.

Es incluso posible que detrás del retablo mayor, en el muro testero, haya o hubiera en el pasado, una escena pintada que representase a Cristo, como en el caso de Curahuara de Carangas, o a la Virgen en su Asunción, que se encuentra en talla sobre el tabernáculo; lo segundo tiene sentido, ya que los relatos sobre la muerte de María procedentes de los evangelios apócrifos, populares en la época virreinal, señalan que los Apóstoles se reunieron milagrosamente en torno a su lecho de muerte y que Jesús socorrió a su Madre en su última hora acompañado por los Arcángeles Miguel y Gabriel. Al igual que la fachada de Cochamarca, este presbiterio es una lección amena y atractiva sobre la Asunción de la Virgen al Cielo en cuerpo y alma, entonces todavía una creencia eclesial -pues no se convirtió en dogma hasta 1950 con la bula Munificentissimus Deus de Pío XIIpero que ya contaba con un arraigo milenario y que además esclarecía otros asuntos marianos que los fieles debían asimilar, como su Concepción Inmaculada, su Maternidad Divina y Virginal o su papel mediador e intercesor, todos derivados de su santidad única. 
De hecho algunos templos conservan murales de los siglos XVI o XVII en el muro testero, detrás del retablo mayor; es el caso de Santa María Magdalena de Pachangara, San Martín de Taucur, San Pedro de Tongos o San Martín de Maní, aunque probablemente hay otros. Los de Taucur, Tongos y Maní muestran escenas relacionadas con el santo patrón de cada lugar, pero los de Pachangara son muy interesantes. Los paños que perviven, dispuestos alrededor de una ventana situada detrás de la imagen de Cristo Crucificado en el retablo, representan el Sol, que simboliza tanto a Cristo como Luz del Mundo como la Eucaristía. Este espacio era una especie de tabernáculo ilusionista adornado con cortinas regias y atendido por ángeles turiferarios en el que la luz del sol inundaba literalmente el espacio a través de la ventana abierta para anunciar la Luz de Cristo. Murales como este y los de las iglesias arriba mencionadas son un testimonio visual de la primera evangelización de esta parte de las Américas, que prácticamente solo se conoce por textos religiosos y documentos eclesiásticos, y por consiguiente deben ser conservados y dados a conocer.

Figura 6. Muro testero de Santa María Magdalena de Pachangara.

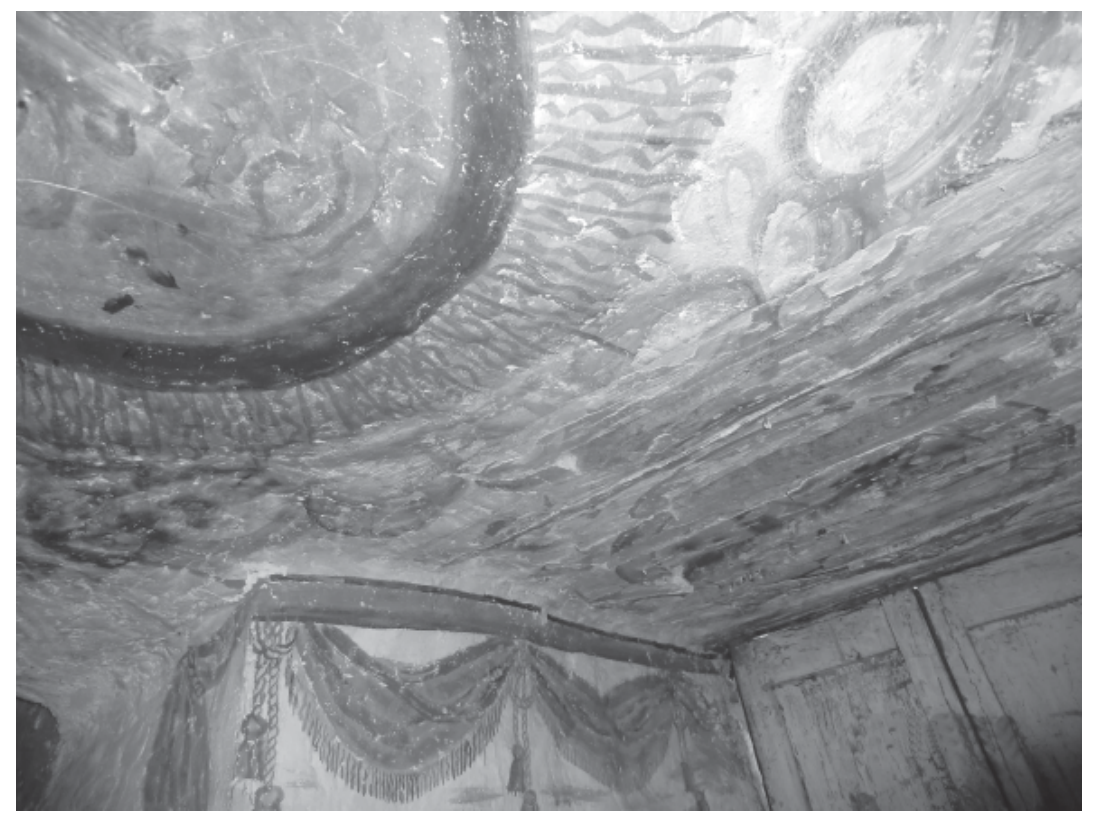

Fuente: Archivo fotográfico de Marco Antonio Arias Salazar.

Otras iglesias muestran escenas de la vida de Cristo, la Virgen, santos, Apóstoles o Evangelistas en el arco toral y en los pilares que lo sujetan. Una vez más citamos el ejemplo de la magnífica iglesia de San Agustín de Canín: el lado que mira al presbiterio muestra a San Juan Nepomuceno a la izquierda, un ángel con trompeta entre nubes en el centro y San Juan Bautista a la derecha; en los pilares están representados San Ildefonso de Toledo (a la izquierda si nos colocamos frente al altar) y San Agustín (a la derecha). La cara del arco que mira hacia la nave tiene en el medio una imagen de la Santísima Trinidad como tres personas idénticas que replica la del retablo mayor; a su izquierda se ve un ángel cargando un incensario flotando entre nubes y cabezas de querubines y a su derecha otro similar que en este caso lleva una copa de incienso. Los arranques muestran las efigies de los Evangelistas San Mateo (con el toro, a la izquierda) y San Juan (con el águila, a la derecha), y en los pilares se representa a Santo Domingo (izquierda) y San Francisco (derecha). 
Este arco exhibe un conglomerado de devociones antiguas y más modernas. Es interesante la presencia de San Juan Nepomuceno junto a San Juan Bautista en la cara que mira al presbiterio, pues estos santos aparecen juntos, en pareja, en otros contextos, como por ejemplo, el retablo de San Nicolás de la iglesia de San Juan de Dios de Cádiz (España), o un delicado dibujo atribuido al pintor italiano Jacopo Amigoni que se conserva en el Museo del Prado con el número de catálogo D01076. Según su leyenda, San Juan Nepomuceno fue martirizado y arrojado al río Vlatva (Praga, actual República Checa) por el rey Wenceslao IV de Luxemburgo cuando se negó a violar el secreto de confesión de la reina Ana de Bohemia; enseguida se convirtió en abogado contra las inundaciones y la muerte por ahogamiento (de hecho es patrón de los navegantes), por eso es coherente su asociación con San Juan Bautista, otro santo obviamente relacionado con el agua, en este caso no el que destruye, sino el que conduce a la vida nueva. De hecho nos tienta pensar que los constantes huaycos e inundaciones que afectan a Canín y a los demás pueblos de valle del río Checras pueden haber contribuido a la elección de este programa iconográfico -que además genera una atractiva pareja de santos ‘Juanes’, como la que conforman el Bautista y el Evangelista en muchas obras de arte. Por otra parte San Juan Nepomuceno también era (y es) modelo y ejemplo de lo que debe ser el sacerdote, fiel hasta la muerte en su ministerio; en Canín, representado sobre el arco, parecía velar sobre el doctrinero durante el desempeño de sus actividades eclesiásticas.

Figura 7. Arco toral de San Agustín de Canín.

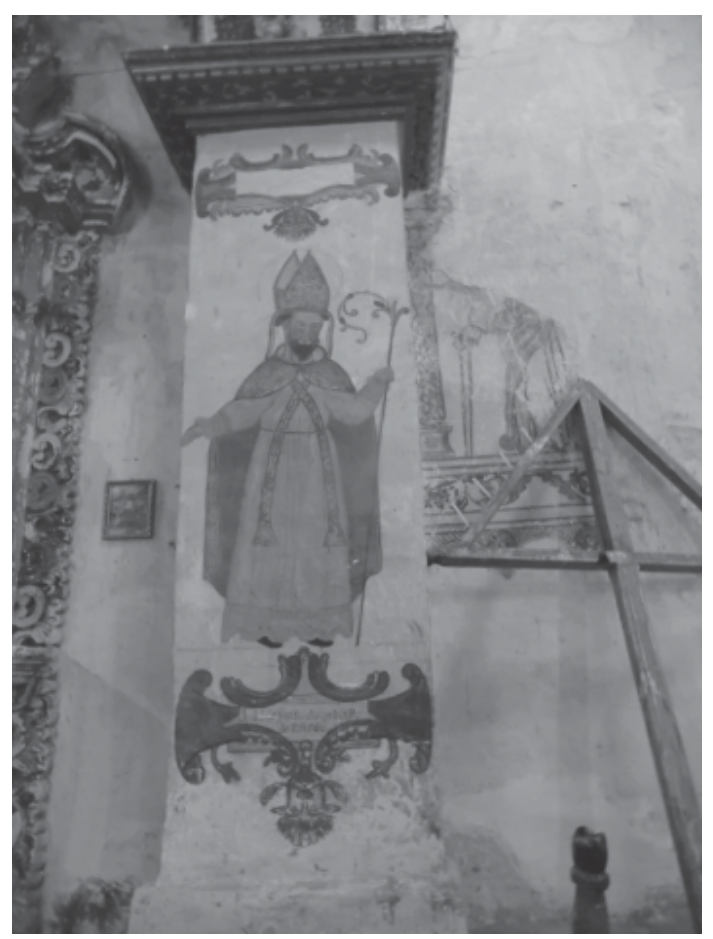

Fuente: Archivo fotográfico de Marco Antonio Arias Salazar.

Continuando con los pilares, la parte del intradós homenajea el origen agustino de esta iglesia: allá aparecen, frente a frente, San Agustín y San Ildefonso (607-667). El primero no necesita presentación, pero el segundo es un santo poco popular fuera de Toledo (España), la ciudad de la que fue Arzobispo, o de contextos agustinos. San Ildefonso escribió, entre otros, el libro Sobre la virginidad perpetua de María contra tres infieles, que se 
apoya mucho en las enseñanzas de San Agustín, y que se considera el arranque de la teología mariana en España. Estamos, por tanto, ante dos colosales mariólogos que se ubican, dentro del arco, en correlación con San Francisco y Santo Domingo. Este programa iconográfico demuestra que los murales que nos ocupan, a pesar de ser 'rurales', contienen complejos programas didácticos y condensan la evolución de la doctrina cristiana con devociones del pasado y del presente (mártires, teólogos, advocaciones marianas) que conviven en el mismo espacio para ejemplo, instrucción y consuelo de los fieles.

Los murales de los templos andinos obligaban al visitante a involucrarse en su propia evangelización: parafraseando a Simon Schama en la serie de la BBC Civilizations, demandaban que uno identificase, encontrase y reencontrase por sí mismo las historias que ya conocía de oídas (2018). En estos lugares el espectador no podía ser un consumidor pasivo de imágenes religiosas: debía convertirse en un intérprete activo de las mismas. Un ejemplo magistral son las pinturas del interior de San Martín de Maní, deterioradas pero fácilmente restaurables, representan escenas de la Pasión de Cristo en orden secuencial, con lo que los fieles podían reflexionar sobre el padecimiento, muerte y Resurrección del Redentor según caminaban a lo largo de la nave o la recorrían mentalmente. Estos murales están inscritos con textos, tanto en prosa como en verso; la prosa está copiada de Diferencia entre lo temporal y lo eterno, crisol de desengaños, con la memoria de la eternidad, postrimerías humanas, y principales misterios divinos, un libro de meditaciones del P. Eusebio Nieremberg, S. J., escrito en 1640 pero con múltiples reediciones hasta bien entrado el siglo XVIII, incluso cuando los jesuitas habían sido expulsados de los territorios españoles. Las partes en verso están tomadas del poema anónimo Ansias amorosas de un alma contrita a un crucifijo, una meditación sobre la Pasión al parecer bastante popular en el siglo XVIII, ya que se imprimía independientemente y hoy día quedan varios ejemplares en distintas bibliotecas; el P. Nieremberg lo recoge en su libro como apéndice.

Murales como los de Maní aportan bastante a nuestro conocimiento de la arquitectura vernácula andina en cuanto a contenido e inspiración intelectual, pues casi sorprende encontrar un programa tan erudito en un pueblo tan pequeño y remoto. También son interesantes porque generan una experiencia kinestética en el público, pues incitan a un desplazamiento físico que, combinado con música, fragancias de flores e incienso y otras decoraciones religiosas, crea una vivencia multisensorial que va más allá de la mera contemplación pasiva. De ahí la importancia de preservarlos e incorporarlos al discurso sobre la historia del arte peruano.

Pero este tipo de pinturas no solamente tenía como fin el adoctrinamiento religioso, sino que en ocasiones enviaba mensajes políticos. Un ejemplo es la techumbre que cubre el presbiterio de la iglesia de San Pedro de Naván, que según la arquitecta Patricia Navarro Grau fue decorada en 1821 (comunicación personal) y no presenta repintes ni intervenciones posteriores; la escena representa a dos ángeles sosteniendo una corona sobre un medallón y una cinta que lleva los colores de la bandera peruana. La cartela central tiene la inscripción en latín Magnificat anima mea Dominum: Et exultavit Spiritus meus in Deo Salvatore meo, quia respexit humillitatem ancilla suae: ecce enim ex hoc beatam me dicent omnes generationes, quia fecit mihi magna qui.

Se trata del texto del Magnificat; es decir, la oración que la Virgen entonó después del saludo a su prima Isabel, embarazada de San Juan Bautista, que comienza con las palabras: Mi alma glorifica al Señor y mi 
espíritu se regocija en Dios mi salvador, porque se ha fijado en la humilde condición de su esclava. Desde ahora me llamarán dichosa todas las generaciones, porque el todopoderoso ha hecho conmigo cosas grandes.

Esta plegaria alude al hecho de que, como ya se ha apuntado, María es compendio de la Iglesia, la Nueva Eva; en su persona se cumple lo antiguo y comienza lo nuevo. Es por tanto, una canción de regocijo, y de hecho existen en la bóveda representaciones de ángeles con instrumentos musicales que adornan la escena central, a los que se une el Rey David escribiendo los Salmos con el arpa tras su trono. Si la fecha de 1821 es correcta, podríamos estar ante una de las primeras manifestaciones artísticas de la emergente república peruana, que casi podría fungir como símbolo del optimismo que se sentía ante la proximidad de una nueva era libre del yugo español.

Figura 8. San Pedro de Naván, murales del presbiterio.

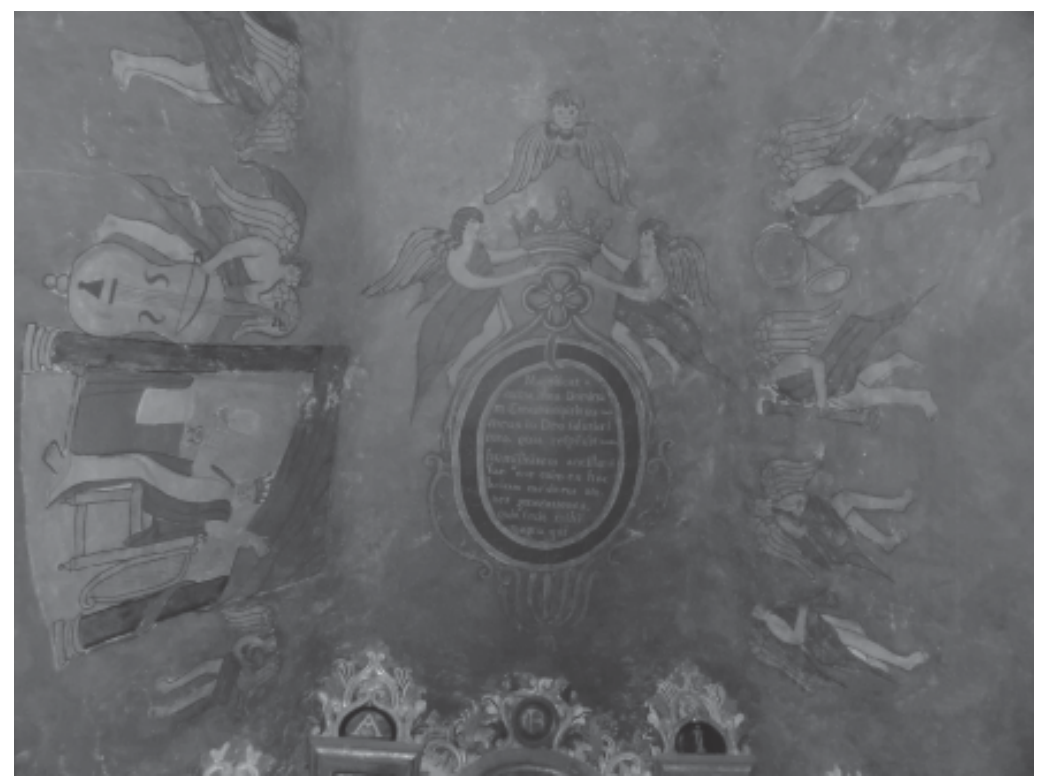

Fuente: Archivo fotográfico de Marco Antonio Arias Salazar.

Pasando a otro campo igualmente importante, los retablos policromados que hoy vemos se construyeron en su mayoría en los siglos XVIII y XIX, y a juzgar por la documentación, mayoritariamente tras el sismo de 1746, que causó considerables destrozos en toda la región Lima. Están profusamente decorados con esculturas, colores y a veces pan de oro. Tienen columnas salomónicas, ángeles tenantes y cariátides flanqueando los nichos y cornisas. El retablo de Quichas es de madera (Patricia Navarro Grau, comunicación personal), pero los demás son de yeso: más simples, como el de Palpas, o exuberantes, como los de Lancha, Pachangara, Acaín, Picoy, Yarucalla, Calpa o Maní. También existen algunos neoclásicos con la estética que en Europa se conoce como 'estilo imperio’, que se popularizó con la llegada de la República e incluye columnas de fuste liso, guirnaldas, lazos, soles radiados, cortinillas fingidas y urnas en forma de jarrón; es el caso de las iglesias de Cochamarca y Huancahuasi. Estos retablos muestran diversas modas artísticas y su difusión e interpretación en un programa coherente junto con los murales despertaría sin duda el interés del potencial turista. 
Otros elementos que estos edificios comparten son un coro de madera con balaustres torneados, un púlpito de ese mismo material o de yeso y un órgano tipo realejo. Los púlpitos añaden belleza y variedad a los interiores, ya que suelen estar decorados con motivos vegetales de inspiración clásica (como el de La Chimba) o con las efigies de los Doctores de la Iglesia Latina (como el de Picoy), los Cuatro Evangelistas (como los de Quichas y Acaín) o importantes santos como San Pedro, San Pablo, Santo Domingo y San Francisco (es el caso de Parquín). Todas estas figuras representan la Sagrada Escritura y la doctrina cristiana que se predica y analiza en la casa de Dios. Entre los púlpitos sin duda destaca el de Santa María Magdalena de Pachangara: se compone de una base, un soporte en forma de columna y un balcón: este último constaba originalmente de siete paneles, pero en la actualidad solo subsisten cinco. El del centro muestra a la Virgen María en su Inmaculada Concepción; los situados a su derecha presentan las efigies de San Ambrosio de Milán, San Gregorio y San Agustín, tres Padres y Doctores de la Iglesia latina que además fueron distinguidos mariólogos. A la izquierda de la Virgen se sitúa un panel con la imagen de San Pedro Pascual, un mercedario del siglo XIII a quien en la Edad Moderna se atribuían escritos en defensa de la Inmaculada Concepción de la Virgen (Disputa del bisbe de Jaén contra los juheus sobre la fè cathòlica). Quizá los paneles perdidos a la izquierda de la imágen de San Pedro Pascual representasen a otros santos mercedarios, posiblemente a San Pedro Nolasco y San Ramón Nonato, muy devotos de la Virgen, y los tres funcionasen como contrapartida a los dedicados a los Padres de la Iglesia. Pero no estamos hablando solo de propaganda teológica ya que este púlpito es también una obra maestra de propaganda mercedaria. La Orden de Nuestra Señora de la Merced, a pesar de su antigüedad, solo vio a sus primeros santos canonizados en el siglo XVII: San Pedro Nolasco lo fue en 1628, San Ramón Nonato en 1657 y San Pedro Pascual en 1670. Al colocar a sus recién estrenados santos junto a María Inmaculada y al mismo nivel

Figura 9. Púlpito de Santa María Magdalena de Pachangara.

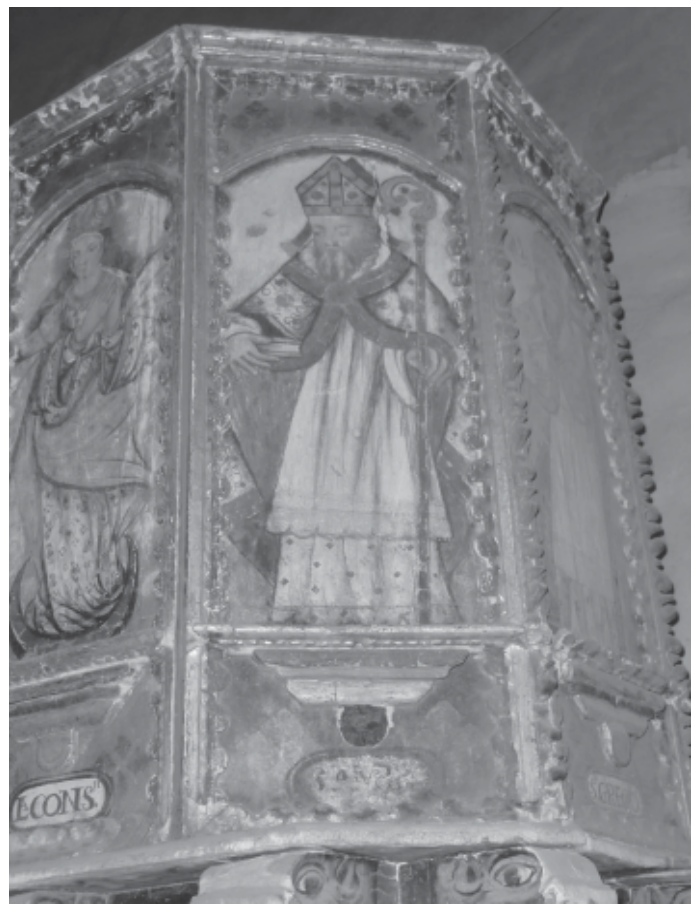

Fuente: Archivo fotográfico de Marco Antonio Arias Salazar. 
que tres Padres y Doctores de la Iglesia latina los mercedarios proclamaban su calibre intelectual y su papel activo en la definición de la doctrina cristiana.

Ejemplos como este y los descritos anteriormente muestran por qué la sierra de Oyón y Huaura tiene muchas posibilidades de convertirse en un destino cultural atractivo, además de en un foco de difusión de historia moderna (y prehispánica, ya que casi todos los pueblos cuentan con zonas arqueológicas preincas). En este sentido, y puesto que el pueblo de Rapaz ya es conocido por su iglesia y su qhipu y recibe visitantes, promocionar las iglesias locales es una oportunidad para ampliar el conocimiento general del público en lo que al pasado peruano se refiere, y ayudar a formar unas nuevas generaciones con más capacidad crítica en la percepción de su historia.

\section{Origen e importancia histórica}

La mayoría de los templos cuya puesta en valor sugerimos tienen un origen muy antiguo. El historiador Jesús Elías Ipinze Jordán afirma que las provincias de Oyón y Huaura tuvieron asentamientos de españoles desde una época inmediatamente posterior a la fundación de Lima (1535). Los actuales distritos de Checras, Paccho e Ihuarí formaban un solo partido que pasó a ser encomienda bajo el nombre genérico de 'indios Checras', 'Canchas’ o 'Maray', el gobernador Francisco Pizarro se lo concedió al conquistador Francisco Velázquez de Talavera. La parte de la provincia Oyón que nos concierne formaba parte del extenso repartimiento de Andax o Andaxes (Andajes), que Pizarro otorgó al también conquistador Hernando de Montenegro el Viejo junto con el de Atavillos. Ipinze indica que las primeras fundaciones de pueblos a la usanza española, determinadas por el progreso de los establecimientos de facto, se produjeron a partir de 1551, año en que se promulgó la Ordenanza Real Española de 21 de marzo (la primera de las Leyes Generales de Indias). Los encomenderos tenían la obligación, por mandato real, de hacer iglesias en los pueblos bajo su jurisdicción y poner en ellas cruces y las imágenes de Cristo y la Virgen. Debían pagar, de los tributos de los propios pueblos, a un clérigo o religioso para que inculcase la fe católica a sus encomendados, y si no hubiera ninguno disponible, a "una güena [sic] persona lega de buena hedad y vida y exemplo para que los instruyan y enseñen en la vida y doctrina cristiana y, los haga ir a la iglesia y aconseje a vivir virtuosamente” (Ipinze, 2005, pp. 78-80; Lisson, 1944, p. 66). En estos momentos tempranos de colonización y redistribución de los pobladores de la sierra de Lima el monto a pagar al doctrinero era a elección del dueño de la encomienda.

Le cupo a la Orden de Santo Domingo iniciar la catequización de Checras y Andax, que fue continuada por agustinos y mercedarios. El célebre Fray Domingo de Santo Tomás, O.P., autor de la Grammática o arte de la lengua general de los indios de los Reynos del Perú y del Lexicon o vocabulario de la lengua general del Perú, fue el primer predicador y doctrinero en los numerosos asentamientos de la zona desde 1548 (Álvarez, 1992, p. 32). Las advocaciones de varios de los pueblos de Checras y Andajes denotan la influencia de los dominicos, como Santo Domingo de Jucul y Nava, Santo Tomás de Cochamarca, Nuestra Señora del Rosario de Calpa y San Juan Bautista de Caujul o Moyobamba (la Orden de Predicadores había puesto su provincia peruana bajo la protección de San Juan Bautista). Ipinze (2005) afirma que la denominación de Santiago, grito de guerra español, se aplicó a las primeras iglesias y asientos o doctrinas, por lo que Maray sería el asentamiento inicial en la encomienda de Talavera; si esto es correcto, explicaría por qué la advocación del pueblo de Andajes, cabeza de repartimiento, es también Santiago (pp. 84-85). 
Los padres agustinos se dirigieron a la entrada de la sierra de Checras y Andajes por invitación de Rodrigo Niño de Guzmán y su esposa Doña María de Valverde, encomenderos de Ocros y Lampas, quienes también poseían el ingenio de la Barranca. Los primeros en llegar fueron Fray Juan Ramírez y Fray Gonzalo de Santiago, a quienes se unió Fray Francisco Martínez de Biedma en 1561 (Uyarra, 1972, p. 175): el cronista Fray Antonio de la Calancha le atribuye una muy exitosa campaña evangelizadora en todos los lugares que pisó (Calancha, 1639, pp. 626-633). Por esta vía pudo penetrar la Orden de San Agustín en la zona que nos interesa, donde habría realizado fundaciones de asientos e iglesias como San Agustín de Canín y Puñún (Checras), y quizá San Ildefonso de Yarucalla (Andajes), dada la preferencia de los agustinos por el Padre de la Iglesia toledano, a quien dedicaron muchas parroquias y colegios en todas sus provincias.

Fray Francisco Marínez de Biedma dejó Ocros, Lampas y Barranca poco antes de ser nombrado Superior del Convento de San Agustín de Lima en 1567; lo sucedió como doctrinero el Padre Alonso Maldonado, quien, según Calancha, se quedó con sus compañeros diez años más, por lo que la Orden habría salido de estas doctrinas hacia 1577, pasando entonces las mismas a manos del clero secular (Calancha, 1639, p. 637; Mendiburu, 1876, p. 117).

En cuanto a los frailes mercedarios, como se señaló anteriormente, actuaron en gran parte del repartimiento de Andax, que abarcaba desde el pueblo de Nuestra Señora del Valle de Quintay, situado cerca de la costa en la actual provincia Huaura, hasta la villa minera de Nuestra Señora de la Asunción de Oyón, incluyendo los actuales distritos de Cochamarca, Naván, Caujul, Andajes, Pachangara y Oyón (Pereyra, 1984-1985, p. 91). Es muy probable que fuera el carismático Fray Diego de Porres o Porras, más conocido por su labor evangelizadora en Santa Cruz de la Sierra, quien coordinara las primeras entradas de los padres de La Merced en la zona, ya que él mismo misionó tres años en Checras y Atavillos, zona esta última encomendada a Hernando de Montenegro el Viejo y sus herederos junto con Andax (Barriga, 1942, pp. 145-148).

El historiador Hugo Pereyra Plasencia indica que, a diferencia de la mayoría de los pueblos de la zona, formados a partir del despoblamiento de antiguos centros prehispánicos, el origen de San Juan Bautista de Churín parece estar asociado a la historia del obraje textil que allí funcionó durante la época virreinal, fundado por Hernando de Montenegro el Viejo a comienzos de la década de los años 60 del siglo XVI. La primera referencia completa al nombre de San Juan Bautista de Churín aparece en un informe redactado por Alonso de Alvarado, Corregidor de Cajatambo, el 3 de septiembre de 1587. Eventualmente la capilla del obraje dio lugar al templo del pueblo (Pereyra, 1984-1985, p. 215).

A fines del siglo XVI la existencia de las doctrinas ya es patente. El documento del Oficial Mayor de la Gobernación Francisco de Avendaño titulado Doctrinas que están a cargo de los religiosos de la Merced en el Arzobispado de los Reyes, en repartimientos de indios y del estipendio anual asignado a los doctrineros, que data del 6 de abril de 1598, refleja que "En el repartimiento de Andaxes de la encomienda de doña Lucía de Montenegro [nieta y heredera de Hernando de Montenegro el Viejo], hay tres beneficiados, los dos frailes de la Orden de la Merced, y el otro clérigo, y a los dos frailes se les da de sígnodo [sic] cada año con mil pesos corrientes” (como se citó en Barriga, 1954, pp. 139-142). Este enunciado indica que en esa época Andax ya estaba dividido en las tres doctrinas que eventualmente se llamaron Santiago de Andajes, San Juan Bautista de 
Churín y Santo Tomás de Cochamarca, quedando las dos primeras en manos de la Orden de Nuestra Señora de la Merced y la última a cargo del clero secular.

En efecto, la denominación de las doctrinas cambió con el tiempo, en un principio derivaba del nombre de los repartimientos o encomiendas, pero más tarde se impuso el del pueblo principal junto con su advocación; así se deduce, por ejemplo, del Libro de Visitas de Toribio Alfonso de Mogrovejo, custodiado en el Archivo del Cabildo Metropolitano de Lima. El santo Arzobispo visitó Checras y Andax en dos ocasiones, 1589 y 1604, su libro nos informa que el primero de estos repartimientos correspondía, en términos eclesiásticos, a la Doctrina de San Pedro de Paccho de Checras, que estaba a cargo del Licenciado Garavilla. A ella pertenecían los pueblos de Santo Domingo de Apachi, San Pedro de Paccho, San Pablo de Ayaranga, San Pedro de Tongos, San Agustín de Puñún, Santiago de Maray, San Agustín de Canín, San Juan de Moyobamba y San Miguel de Parquín. Santo Toribio lista otro pueblo entre Moyobamba y Parquín, su nombre no se puede leer porque el folio correspondiente (251r) está deteriorado, pero por razones geográficas debe tratarse de Santo Domingo de Jucul.

Pocos años después, sin embargo, el término Doctrina de San Pedro de Paccho se aplicaba solo a la propia localidad de Paccho y sus pueblos aledaños, mientras que las localidades de Maray, Tongos, Puñún, Canín, Parquín, Moyobamba y Jucul, junto con San Juan Bautista de Tulpay y San Bartolomé de Picoy, constituyeron la Doctrina de Santiago de Maray.

Por su parte Andax, el Libro de Santo Toribio indica que sus tres doctrinas se conocían entonces como Doctrina de la Collana de Andaxes, Doctrina de Cauxol (Caujul) en Andax y Doctrina de Santo Tomás de Cochamarca. La primera contenía los pueblos de San Cristóbal de Rapaz, San Martín de Taucur, San Bartolomé de Curay, San Pedro de Palpas, La Magdalena de Pachangara, Santo Domingo de Nava (el escribano de Santo Toribio escribe Navan, quizá por equivocación con San Pedro de Naván, al otro lado del río Huaura), Nuestra Señora de la Asunción de Hojón (Oyón) y San Sebastián de Molino Tinto (actualmente Tinta). Entre los pueblos de Curay y Palpas se cita otro, aunque el nombre no se puede leer por el deterioro del folio (252r); dada la geografía de la zona, suponemos que se trata de La Limpia Concepción de Huacho. La lista de pueblos de la Collana de Andajes se cierra con una localidad cuyo nombre tampoco se lee por rotura del Libro, pero que, si seguimos el itinerario del ilustre Arzobispo, correspondería a Nuestra Señora de las Nieves de Mallay, conocida entonces como Nuestra Señora de las Nieves de Barrios. El Libro menciona también la visita al obraje de Juan Gutiérrez Flórez; es decir, el de Churín, ya que Gutiérrez estaba casado con la encomendera Lucía de Montenegro. La doctrina de la Collana de Andaxes, a fecha de 1604, la servía Fray Pedro de Santa María, O. de $\mathrm{M}$.

El nombre de esta demarcación eclesiástica eventualmente perdió la referencia a sus pobladores originales, los ‘indios’ Andajes, y cambió a Doctrina de San Juan Bautista de Churín. Entonces el término ‘Andajes' se ciñó a lo que Toribio de Mogrovejo llama Doctrina de Cauxol (Caujul) en Andax, y que durante los siglos XVII y XVIII se conocía indistintamente como Doctrina de Santiago de Andajes o de San Juan de Caujul, como prueban abundantes causas de visitas pastorales custodiadas en el Archivo del Obispado de Huacho. Esta doctrina también estaba en manos de los frailes mercedarios (parece que en el folio 254r del Libro de Visitas se lee el nombre rrufino para el religioso que la servía en el año de 1604), y en época de Santo Toribio contaba con seis 
pueblos: el propio Santiago de Andajes, San Benito de Caraz, San Juan de Caujul, San Pedro de Naván, San Jerónimo de Conchao y Los Santos de Guanangui. La huella de los mercedarios es visible en la iconografía de sus templos, en especial en el de Santiago de Andajes y en el de Nuestra Señora de la Merced de La Chimba.

En cuanto a la tercera doctrina que surgió en el repartimiento de Andax, Santo Tomás de Cochamarca, parece que siempre estuvo a cargo del clero secular: el Libro de Monseñor Mogrovejo cita en folio 256v un "Padre Diego (...) [roto] [clér]igo" como responsable de la misma, y el expediente del Archivo General de Indias Relación de las Ciudades, Villas y lugares, Parrochias y Doctrinas que ay en este Arçobispado de Lima (...), del año 1619, constata que el cura era entonces el Licenciado Alonso Osorio, se trata del famoso Alonso Osorio, protegido del Arzobispo Bartolomé Lobo Guerrero (1609-1622), a quien el P. Pablo Joseph de Arriaga, S. J., menciona como visitador de la idolatría y descubridor de brujos en Cochamarca. Esta doctrina tenía ocho pueblos en época de Santo Toribio, cuyo Libro los cita en el siguiente orden: San Miguel de Guacac (Huacá), San Ildefonso de Yarocalla (Yarucalla), Santo Tomás de Cochamarca, un pueblo con nombre ilegible por rotura del folio 256r que podría ser San Juan de Aynaca o San Martín de Maní, San Miguel de Guamancaca, Santa Lucía de Arará, Nuestra Señora del Rosario de Calpa y Santa María de Lupiqueyunga (suponemos que Liple). En 1619 esta demarcación religiosa se había reducido a seis pueblos: Cochamarca, Huacá, Yarucalla, Maní, Calpa y Aynaca, “todos con iglesia y pila bautismal”. Algunos templos virreinales de esta zona apenas han sido alterados desde el siglo XVIII, como los de Calpa y Maní.

Las iglesias que nos ocupan habrían tenido un origen humilde por falta de materiales, mano de obra especializada y artistas. Posiblemente comenzaran sus días como una simple construcción con los elementos mínimos para la celebración de la Eucaristía. Sobre ello da testimonio la Instrucción de la horden que se a de tener en la doctrina de los naturales de Monseñor Jerónimo de Loayza, O.P., primer obispo de Lima, fechada en 1541:

Primero encargamos a los susodichos [i. e., los doctrineros] que tengan especial cuidado no haziendo sobre ello vexación a los yndios, que en el pueblo donde residiere el cacique principal se haga una casa a manera de yglesia donde los yndios se junten a oyr la doctrina xpiana [christiana] y donde se diga mysa, adornando el altar de la mejor manera que se pudiere y poniendo en él alguna ymagen o ymágenes; y para que en la dicha casa se administren los sacramentos del baptismo y matrimonio y penitencia, no consintiendo ni dando lugar que en la dicha yglesia se junten para otra cosa más de para la administración de los santos sacramentos, como dicho es, y para doctrinarlos en las cosas de nuestra santa fee y conoscimiento de dios nuestro señor. (como se citó en Lisson, 1944)

El Obispo Loayza añade una reflexión a su mandato:

[Aunque esa casa improvisada no sea en principio] verdaderamente iglesia, se le a de tener Reverencia para que entiendan el acatamiento que los xpianos [christianos] tenemos a los templos de Dios, y el efecto para que se hazen, que es para ayuntarlos a dar gloria a Dios, y alavalle y a oyr los oficios divinos y Recibir los sacramentos y oyr su doctrina y pedir perdón de nuestros pecados. (como se citó en Lisson, 1944, pp. 135-136) 
Igualmente, la Constitución 3 del primer Concilio Limense (1551-1552), convocado y presidido por el mismo prelado, determina que si en pueblos de indios cristianos hubiere ídolos y adoratorios, sean quemados y destruidos, y que si el lugar fuera decente, se edifique una iglesia, o al menos se ponga una cruz (Aparicio, 1992, p. 102).

Un documento fundamental para entender la vida temprana de templos rurales como los de los repartimientos de Checras y Andax es la Ynstrucción, y orden que an de tener, los saçerdotes, que se ocuparen en la doctrina, y conversión de los yndios, en las yndias del Pirú, y en las demás (...) de Diego de Porres, O. de M., antes mencionado como evangelizador de Checras y Atavillos. Había de estar siempre abierta excepto en la noche, como una casa acogedora, con sacristanes o “yglesiacamayos» cuidándola por turno de mita. Debía ser barrida y regada «todos los días de esta vida”, y los domingos y fiestas, enramada y adornada con flores. Su plaza era el espacio donde el doctrinero reunía a la gente, chicos y grandes, cada uno por su orden de censo, para predicarles la doctrina, y antes de viajar a otro pueblo, para recordarles lo que debían creer y obrar e instarles a practicar el amor y la caridad al prójimo y a reflexionar sobre la muerte y el Juicio Final. La plaza era también el lugar donde el pueblo se juntaba los miércoles y domingos para rezar las oraciones obligatorias y escuchar los coloquios de los muchachos catequistas, acto que terminaba ceremoniosamente en el templo, donde los concurrentes se hincaban de rodillas y rezaban, acabando con la confesión general (Archivo General de Indias, Patronato, 231, N. 7, R. 8 sin foliar).

La iglesia y su espacio circundante funcionaban, además, como solemne escenario de corrección y castigo, pues allí se cumplían las penas de azotes impuestas por el sacerdote a las personas que aún practicaban ritos precristianos, como el trasquilado de niños, o a las que faltaban a la doctrina o descuidaban sus oraciones a las Ánimas del Purgatorio. También a los ladrones, a los difamadores y a aquéllos desobedientes de su cacique, puesto que uno de los objetivos de la catequización era dotar de 'policía' a los indios. Según la Ynstrucción, el sacerdote incluso tenía la potestad de deponer a los malos alguaciles y de devolverles sus varas si cambiaban de actitud, actos que también se realizaban delante de la iglesia. En estos momentos tempranos de la evangelización del Perú, la imagen que el Padre Porres presenta del doctrinero no es solo la de un catequista y erradicador de idolatrías, sino la de un juez que compone diferencias, remedia agravios y restituye a cada uno lo suyo, es decir, pone orden en el caos y convierte las reducciones a su cargo en espejos de la Ciudad de Dios, presididas por la Casa del Señor -el templo-.

Como todo edificio histórico, los templos de la sierra de Oyón y Huaura han sufrido multiples transformaciones, sobre todo debido a los sismos: en los años 60 y 70 del siglo XX derribaron torres y arruinaron algunas iglesias, como las de Churín, Tinta o Chiuchín, que tuvieron que reedificarse por completo, por esa razón, a menudo el mobiliario virreinal que hoy observamos en estos lugares ha sido reparado, reposicionado y hasta reciclado, pero eso no los hace menos interesantes; al contrario, muestra que son testigo de los avatares del tiempo y no simples 'reliquias' intocadas. El relato de sus circunstancias nos proporcionan valiosos datos sobre la historia local, no solo desde el punto de vista artístico, sino también político, social y de las mentalidades, al igual que sobre las dinámicas internas de los Andes de Lima como espacio regional definido por las doctrinas. 


\section{Posibilidades de desarrollo turístico}

A continuación ofrecemos algunos apuntes que podrían ser útiles a la hora de implementar rutas turísticas las cuales podrían articularse a partir del patrimonio arquitectónico descrito y la diversidad de otros recursos naturales y culturales con que cuenta la zona.

Para empezar, como es conocido, Churín tiene aguas termales con propiedades mundialmente reconocidas; también hay baños en otros lugares cercanos como Viroc, Mallay, Huancahuasi, Chiuchín y Picoy, a los que no se les da la publicidad que merecen. La pista (18) de Churín a Oyón está asfaltada y la distancia es corta; se pasa por desvíos a varios pueblos con templo virreinal, como Nava, Mallay, Palpas o Pachangara, por no hablar del propio Oyón. Conviene resaltar que en ruta se atravieza un tramo del Qhapaq Ñan en Ayarpongo que está señalizado pero no propiamente difundido; por otro lado, desde el propio Churín se puede cruzar a pie el río Huaura por el puente y acceder a la bellísima iglesia de Nuestra Señora de la Merced de La Chimba. Los pueblos en la ruta hacia Oyón tienen zonas arqueológicas espectaculares, y antes de entrar en esa localidad hay un desvío hacia Ucruzchaca y Quichas; ambas localidades tienen lo que fueran capillas de ingenio. Desde Quichas hasta la mina de Raura las posibilidades para el turismo natural y de aventura se multiplican, con asombrosos paisajes y escenarios como la laguna Anamaray. Esta ruta se podría implementar sin mucho esfuerzo, ya que Churín y Oyón cuentan con infraestructura turística y servicios médicos; el primero es una buena base para explorar la zona, pues tiene alojamientos para todos los bolsillos y también da acceso a otro grupo de iglesias interesantes siguiendo el curso del río Checras, sin ir más lejos las de Huacho Sin Pescado, Curay, Acaín o Tongos. En Ayarpongo, que está a una breve caminata de Churín, hay piscigranjas donde se puede degustar trucha; son populares entre las personas que visitan los baños. Volviendo a Oyón, indicamos que está en el camino hacia la iglesia de San Cristóbal de Rapaz, cuyos murales le han merecido la calificación de Capilla Sixtina de los Andes (o al menos de esta parte de los Andes, pues el título se lo disputa con San Pedro de Andahuaylillas, en la zona de Cusco). Rapaz, que también cuenta con un famoso qhipu, está cerca de Picoy, un pueblo con baños termales y una espectacular iglesia barroca refaccionada en los años 1773-1774; ambas localidades tienen sus respectivos sitios arqueológicos y el área es atractiva para actividades como trekking. Picoy se puede alcanzar desde Churín con las movilidades que van a los baños, las cuales también paran en Huancahuasi, cuya capilla, como dijimos, conserva un interesante retablo republicano en su interior.

Desde Churín, girando a la izquierda por la pista 107 en Puente Tingo, se accede a varios pueblos con iglesia virreinal: Tongos, Tulpay, Puñún, Canín, Parquín, Jucul y Moyobamba (también se encuentra un desvío a Picoy, desde, como acabamos de indicar, se llega a Rapaz). Destacamos el magnífico templo de San Agustín de Canín, algunos de cuyos rasgos notables se han discutido anteriormente. Existen servicios adecuados en Chiuchín, incluyendo hospedajes, restaurantes campestres, baños termales y piscigranjas, por lo que es una parada conveniente, ya que sería imposible disfrutar de todas las iglesias, sitios arqueológicos, baños y atractivos naturales de esta ruta en un solo día.

Por otro lado, el bellísimo pueblo de Andajes, con su soberbio templo, se alcanza cómodamente desde Ayarpongo, con lo que se podría incluir sin problema en circuitos turísticos desde Churín. Para llegar a otros lugares de esta parte, como Naván o Caujul o Lancha, hay desvío en la pista 18 antes de Puente Tingo, lo 
mismo que para Cochamarca, Calpa o Maní (el Puente de Choques); aunque estas últimas localidades son remotas, se puede efectuar una parada en el asentamiento de Colcapampa de Maní, que cuenta con lugares para comer, bodegas y servicios higiénicos, y sobre todo con lugareños maravillosamente hospitalarios. Cochamarca es municipalidad distrital y por tanto, aunque de momento no sea un destino popular, dispone de potencial para atender las necesidades del visitante y convertirse en base para explorar la zona.

Los Andes de Lima también tienen inmensos recursos para un turismo vivencial. Todos los pueblos de la sierra de Oyón y Huaura celebran sus fiestas patronales; también suele conmemorarse la Navidad (o el Niño Jesús, como comúnmente lo llaman), la Semana Santa (las celebraciones de Andajes son particularmente recomendables), y otras festividades cuyos orígenes se pierden en el tiempo, como la limpia de acequia o fiesta del agua, el carnaval, el rodeo, las pallas o los negritos; es decir, lo que los lugareños llaman 'la costumbre'. Los visitantes son muy bienvenidos y es una buena oportunidad para apreciar las iglesias, que se limpian y adornan para la ocasión, y para disfrutar de las procesiones, bailes típicos y paraliturgia. Un aspecto importante relacionado con las fiestas es la gastronomía, pues se sirven platos locales como el pari o sopa de piedra, el mondongo o la pachamanca, que se podrían promocionar en términos de turismo gastronómico junto con otros productos de la zona como los quesos y demás lácteos (manjar, yogur, cuajada, leche vinagre, leche asada), la carne, la trucha y el cuy.

Algunos actos de las fiestas costumbristas tienen lugar en las ruinas arqueológicas de los pueblos, ya mencionadas. Este es un punto importante, pues puede ayudar a promocionarlas, además teniendo en cuenta que hay estudios difundidos a nivel local que pueden servir como punto de partida para su interpretación al visitante. Considerando que estos lugares no están tan alejados de yacimientos conocidos como Caral, sugerimos la posibilidad de implementar una ruta de la civilización precolombina en el Norte Chico, que además permita al visitante, si desea ampliar su experiencia, disfrutar de costumbres, gastronomía e historia virreinal.

En conexión con este posible circuito turístico y otros sobre arquitectura virreinal o arte barroco (Picoy y Rapaz harían un tándem perfecto en este sentido) se pueden explotar otros temas de interés para el público, como el itinerario de Santo Toribio de Mogrovejo, pues este ilustre personaje visitó casi todos los pueblos de los valles del Huaura y el Checras, como se mencionó, e incluso los comienzos de la República Peruana, incluyendo las pinturas del presbiterio de San Pedro de Naván y los varios retablos ‘estilo imperio’ que existen en este y otros pueblos; esto tendría sentido, pues el Distrito de Naván está relativamente cerca de Huaura y su patrimonio histórico sobre la Independencia.

\section{Conclusiones}

Los casos estudiados ayudan a apreciar mejor la creatividad inherente a la arquitectura vernácula andina y que su promoción tendría un gran peso a la hora de consolidar al Perú como el importante destino turístico que ya es, sobre todo de cara al Bicentenario de la Independencia. Creemos sinceramente que es una buena apuesta, pues ayudaría a superar la visión sesgada que se tiene de la cultura del país en el extranjero, e incluso en algunos círculos peruanos, basados en la creencia de que el patrimonio artístico nacional se sustenta en los grandes yacimientos prehispánicos o en los impresionantes monumentos llamados 'coloniales', como monasterios, iglesias de la Compañía de Jesús o catedrales. No se puede subestimar la agencia de las iglesias rurales en la 
definición de lo que hoy es la nación peruana, pues eran el lugar donde la gente se concentraba para tomar decisiones, se empoderaba y se autorepresentaba, al fin y al cabo, la historia del arte no es solo la historia de los artistas, sino también de la gente ordinaria que interactuaba con las obras de arte y que muchas veces movía el curso de la historia 'desde abajo'.

En cualquier caso, y para concluir, esperamos haber demostrado que los templos virreinales de la sierra de Lima merecen y deben ser preservados y difundidos, pues su origen y avatares, encajan en los principales temas de la historia peruana y sudamericana en general. Se trata de un patrimonio local y universal, para creyentes y no creyentes.

\section{Referencias}

Álvarez, G. O.P. (1992). Los dominicos en la evangelización del Perú. Siglo XVI. Revista peruana de historia eclesiástica, 2 , 11-52.

Aparicio, S. (1992). Los mercedarios en la evangelización del Perú (s. XVI-XVIII). Revista peruana de historia eclesiástica, $2,91-151$.

Archivo General de Indias, Patronato, 231, N. 7, R. 8 (sin foliar).

Barriga, V. M. (1954). Los mercedarios en el Perú en el siglo XVI, 1537-1614: documentos inéditos del Archivo General de Indias de Sevilla (5 $5^{\circ}$ Vol.). Arequipa: Imprenta Portugal.

Calancha, A. (1639). Corónica moralizada del Orden de San Agustín en el Perú, con sucesos egenplares vistos en esta monarquía. (Tomo primero). Barcelona: Pedro Lacavallería.

Ipinze, J. E. (2005). La antigua provincia de Chancay, siglos XVI-XVIII. Huacho: Comisión de celebración del centenario del nacimiento del historiador Jesús Elías Ipinze.

Lisson, E. (1944) (Ed.). La Iglesia de España en el Perú (Vol. 1). Sevilla.

Mendiburu, M. (1876). Diccionario histórico-biográfico del Perú (Parte primera, Tomo segundo). Lima: Francisco J. Solís.

Obispado de Huacho. (2000). Proyecto de identificación e inventario de conservación: capillas doctrinales de Oyón (Vol. 2). Manuscrito inédito.

Patrimonio Perú. (2006). Proyecto de inventario, catalogación y trabajos de emergencia en 09 capillas doctrinales de Oyón y Huaura (Vol. 3). Manuscrito inédito financiado por World Monuments Fund Robert W. Wilson Challenger [sic] Foundation, Compañía de Minas Buenaventura S.A.A., Empresa Minera los Quenuales, S.A.

Patrimonio Perú y Obispado de Huacho. (2005). Proyecto de restauración y trabajos de emergencia, iglesia de San Cristóbal de Rapaz y su torre exenta; cuenca de Oyón, Lima. Manuscrito inédito. Auspiciado por The Getty Program; World Monuments Fund’s Robert W. Wilson Challenge Foundation.

Pereyra, H. (1984-1985). Mita obrajera, idolatría y rebelión en San Juan de Churín (1663). Boletín del Instituto Riva-Agüero, $13,209-244$.

Rahner, H. (2002). María y la Iglesia. Madrid: Ediciones Cristiandad.

Schama, S. (1 de marzo de 2018). Civilizations, series 1: 9. The Vital Spark, retransmitido por la BBC.

Uyarra, B. O. S. A. (1992). La Orden de San Agustín en la evangelización del Perú, 1551-1600. Revista de historia eclesiástica, 2, 153-187.

\section{Sara González Castrejón}

Licenciada en Humanidades y doctora en Historia del Arte por la Universidad de Castilla, La Mancha (Toledo, España). Investigadora. Ayudante de investigación en el Proyecto "Aztecs Abroad" de la Universidad de Sheffield (Reino Unido). Becaria de British Academy (proyecto SG170102). Ha impartido clases en la Universidad de Londres (Birkbeck) y Oxford University Department for Continuing Education. Entre sus publicaciones se encuentra Templos virreinales de la sierra de Oyón y Huaura: estudio artístico e iconográfico (Lima, Universidad de San Martín de Porres, 2018, en prensa).

gonzalezcass@gmail.com 